\title{
RBM5 wt Allele
}

National Cancer Institute

\section{Source}

National Cancer Institute. RBM5 wt Allele. NCI Thesaurus. Code C51300.

Human RBM5 wild-type allele is located in the vicinity of 3p21.3 and is approximately 30 $\mathrm{kb}$ in length. This allele, which encodes RNA-binding protein 5 , is involved in RNA homopolymer binding and recognition. The gene may have a role as a tumor suppressor in lung cancer. 